\title{
DEVELOPING COMIC MEDIA ABOUT HUMAN INTERACTION WITH THE ENVIRONMENT TO IMPROVE CRITICAL THINKING SKILLS
}

\author{
Lailatul Fitriah $^{1}$, Maria Veronica Roesminingsih ${ }^{2}$, Suhanadji $^{3}$ \\ 1,2,3 Universitas Negeri Surabaya, Surabaya, Indonesia \\ ${ }^{1}$ lailatul.19082@mhs.unesa.ac.id, ${ }^{2}$ roesminingsih@unesa.ac.id, ${ }^{3}$ suhanadji@unesa.ac.id
}

\begin{abstract}
Students' critical thinking has not been maximally trained in learning since learning activities are only memorizing to meet the demands of passing the assessment. Students are less able to understand, build, and criticize arguments about a problem, especially in social studies learning. This study aimed to determine the feasibility of comic media material about human interaction with the environment to improve the critical thinking skills of fifth grade students. This type of research was research and development (Research and Development) with a $4 D$ model. This research was conducted online using Zoom platform, Google forms, and Ms. Teams that was carried out synchronously and asynchronously due to the Covid-19 pandemic. Data were collected through the expert validation stage and observation sheets, student response questionnaires and critical thinking tests (pretest and posttest) for the teacher and student activity. Furthermore, the data were analyzed by quantitative and descriptive techniques. The results showed that: (1) comic media was in the very feasible category with a percentage of $82 \%$, (2) it was practical based on teacher activity observations with a percentage of $94 \%$ with very active category, 95\% for student activity with very active category and student response questionnaires was $93 \%$ with very good category, (3) it was effective based on the result of $N$-gain on the critical thinking test, which was 0.53 (medium category). Thus, comic media in social studies learning was declared valid, practical and effective in improving students' critical thinking skills at fifth grade of elementary school.
\end{abstract}

Keywords: comic media, critical thinking skill, elementary school

\section{PENGEMBANGAN MEDIA KOMIK TENTANG INTERAKSI MANUSIA DENGAN LINGKUNGAN UNTUK MENINGKATKAN KETERAMPILAN BERPIKIR KRITIS}

\begin{abstract}
ABSTRAK
Berpikir kritis siswa belum dilatihkan secara maksimal dalam pembelajaran, kegiatan pembelajaran hanya menghafal untuk memenuhi tuntutan lulus dalam penilaian. Siswa kurang dapat memahami, membangun, dan mengkritisi argumen mengenai sebuah masalah terutama pada pembelajaran IPS. Penelitian ini bertujuan untuk mengetahui bagaimana kelayakan media komik materi interaksi manusia dengan lingkungannya untuk meningkatkan keterampilan berpikir kritis siswa kelas V. Jenis penelitian ini adalah penelitian dan pengembangan (Research and Development) dengan model 4D. Penelitian ini dilakukan secara online menggunakan platform Zoom, Google form, dan Ms. Teams yang dilakukan secara sinkronus dan asinkronus karena pandemi Covid-19. Data dikumpulkan melalui tahap validasi ahli, kemudian untuk lembar observasi aktivitas guru dan siswa, angket respon siswa dan tes berpikir kritis (pretest dan posttest). Selanjutnya, dianalisis dengan teknik kuantitatif dan deskriptif. Hasil penelitian menunjukkan bahwa: (1) media komik berada pada kategori sangat layak dengan persentase 82\%, (2) praktis berdasarkan observasi aktivitas guru dengan persentase $94 \%$ kategoti sangat aktif, aktivitas siswa 95\% kategori sangat aktif dan angket respon siswa yaitu 93\% kategori sangat baik, (3) efektif berdasarkan perolehan $\mathrm{N}$-gain pada tes berpikir kritis yaitu 0.53 (kategori sedang). Media komik dalam pembelajaran IPS dinyatakan valid, praktis dan efektif dalam meningkatkan keterampilan berpikir kritis siswa kelas V sekolah dasar.
\end{abstract}

Kata Kunci: media komik, keterampilan berpikir kritis, sekolah dasar

\begin{tabular}{|c|c|c|}
\hline Submitted & Accepted & Published \\
\hline 26 Juli 2021 & 07 September 2021 & 17 September 2021 \\
\hline
\end{tabular}

\begin{tabular}{|l|l|l|}
\hline Citation & $:$ & $\begin{array}{r}\text { Fitriah, L., Roesminingsih, M.V., \& Suhanadji, S. (2021). Developing Comic Media about Human Interaction with the } \\
\text { Environment to Improve Critical Thinking Skills. Jurnal PAJAR (Pendidikan dan Pengajaran), 5(5), 1415-1433. } \\
\text { DOI : http://dx.doi.org/10.33578/pjr.v5i5.8485. }\end{array}$ \\
\hline
\end{tabular}

\section{PENDAHULUAN}

Pendidikan di sekolah dasar berperan penting dalam penyelenggaraan proses pendidikan pada jenjang berikutnya. Hal ini sesuai dengan Undang-undang RI No. 20 tahun 2003 pasal 17 ayat 1 menyebutkan bahwa pendidikan dasar merupakan jenjang pendidikan yang melandasi jenjang pendidikan menengah. Adapun tujuan dari pendidikan dasar adalah meletakkan dasar kecerdasan, pengetahuan, kepribadian, akhlak mulia, dan keterampilan untuk hidup mandiri dan 
mengikuti pendidikan lebih lanjut (Lampiran Permendiknas No.24 Tahun 2006). Pendidikan tingkat sekolah dasar sesuai dengan Peraturan Pemerintah Nomor 19 Tahun 2005 pasal 26 ayat 1 bertujuan untuk meletakkan dasar kecerdasan, kepribadian, pengetahuan, akhlak mulia, kemandirian hidup, dan mengikuti pendidikan lanjutan (Pidarta, 2013: 12). Jenjang sekolah dasar sangat berperan dalam membangun pengetahuan, keterampilan dan sikap seseorang dalam kehidupan sehari-hari melalui berbagai mata pelajaran yang disajikan di sekolah dasar yang diharapkan dapat membentuk kepribadian siswa menjadi lebih baik.

Johan (2015:339) menjelaskan bahwa pembentukan pengetahuan, keterampilan, dan sikap peserta didik merupakan salah satu hasil belajar IPS. IPS dalam pendidikannya dapat mengembangkan pengetahuan dan keterlibatan dalam masalah warga negara (Nasution, 2015:7). Sesuai dengan pendapat Surahman (2017:3) bahwa pendidikan IPS dapat menjadi konsep dalam pengembangan pengetahuan, sikap dan keterampilan sosial yang bertujuan untuk membentuk dan mengembangkan sikap warga negara yang baik dan merupakan bagian dari wacana kurikulum dan sistem pendidikan di Indonesia. Hasbullah (2015:204) menjelaskan bahwa pengetahuan, keterampilan, dan sikap yang baik diperlukan untuk dipertahankan dalam masyarakat. Dengan demikian, ada tiga aspek yang dibangun melalui pembelajaran IPS di sekolah yaitu sikap, pengetahuan, dan keterampilan yang merupakan bekal untuk hidup bermasyarakat. Ketiga aspek yang berbeda-beda hendaknya dapat tercakup dalam satu kegiatan dan saling melengkapi demi tercapainya tujuan pembelajaran IPS.

Merujuk pada Permendiknas No.22 tahun 2006, bahwa mata pelajaran IPS bertujuan agar peserta didik memiliki kemampuan sebagai berikut: 1) mengenal konsep-konsep yang berhubungan dengan kehidupan masyarakat dan lingkungannya, 2) memiliki kemampuan dasar berfikir logis, kritis, rasa ingin tahu, inkuiri, memecahkan masalah, dan keterampilan kehidupan sosial, 3) memiliki komitmen dan kesadaran terhadap nilai- nilai sosial dan kemanusiaan, dan 4) memiliki kekuatan untuk berbicara, berkolaborasi dan bersaing baik dalam lingkup komunitas lokal maupun global. Sejalan dengan pandangan Susanto (2014:2), IPS bertujuan untuk memahami dan mengembangkan pengetahuan, nilai, sikap, keterampilan sosial, kewarganegaraan, fakta, peristiwa, konsep dan generalisasi serta mampu merefleksikan kehidupan bermasyarakat, berbangsa dan bernegara.

Prinsip-prinsip pembelajaran IPS harus dikembangkan untuk mewujudkan keunggulan dalam pembelajaran IPS, bahwa proses pembelajaran sesuai dengan prinsip-prinsip yang dikembangkan oleh NCSS dalam Nasution (2015:10), diantaranya: 1) pembelajaran IPS yang akan dilaksanakan lebih kuat jika bermakna; 2) pembelajaran IPS lebih kuat bila diintegrasikan; 3) pembelajaran IPS akan lebih kuat jika berbasis nilai; 4) pembelajaran IPS akan menjadi lebih kuat saat menantang; 5) Pembelajaran IPS akan lebih kuat bila aktif. Tujuan pembelajaran IPS adalah melatih siswa agar mampu memecahkan masalah yang terjadi di masyarakat, apalagi di era derasnya informasi seperti saat ini sangat penting mendidik dan melatih siswa berpikir kritis.

Razak (2017:119) menjelaskan bahwa proses pelatihan dan hasil belajar sangat dipengaruhi oleh pemikiran kritis peserta didik dan mempunyai tugas untuk menghasilkan bekal dalam menghadapi masa depan. Menurut Stobaugh dalam Haryanti (2017:60) berpikir kritis adalah kemampuan untuk menghasilkan jawaban yang tidak bersifat hafalan. Hal senada juga dikemukakan oleh Winataputra (2010:78) bahwa peserta tidak hanya belajar dengan cara menghafal tetapi dapat memainkan peran yang kuat dalam proses pembelajaran sehingga mereka mampu mengkontruksi pengetahuan sesuai dengan gagasannya sendiri. Keterampilan berpikir kritis terintegrasi langsung dalam pembelajaran High Order Thinking Skill (HOTS), yaitu pembelajaran dengan melatih keterampilan berpikir tingkat tinggi siswa (Subekti, 2018:3). Jika tidak terlatih berpikir kritis siswa tidak dapat memilih, memilah, dan mengolahnya menjadi pengetahuan, dan sebaliknya jika terbiasa dengan berpikir kritis 
siswa lebih mudah memahaminya, dan guru hanya berfungsi sebagai fasilitator dan motivator.

Berdasarkan hasil observasi dan wawancara pada siswa kelas V SDN Kalidawir Kecamatan Tanggulangin Kabupaten Sidoarjo pada tanggal 3 September 2020 terlihat bahwa kegiatan pembelajaran IPS belum maksimal. Beberapa peserta didik kurang antusias memperhatikan penjelasan guru, tidak menjawab pertanyaan guru, dan kurang aktif mengemukakan pendapat. Selain itu peserta didik merasa jenuh karena menghafal materi dimana cakupannya luas, dan bersifat abstrak sehingga pemahaman siswa terhadap materi masih rendah. Hal tersebut menyebabkan peserta didik tidak benar-benar memahami dan mudah lupa terhadap materi yang dipelajari. Kebiasaan ini menunjukkan gejala menurunnya kemampuan berpikir kritis karena peserta didik enggan menggunakan logika berpikirnya. Maka guru perlu menelaah apakah peserta didik telah menggunakan logika berpikir atau tidak sesuai dengan tujuan pembelajaran IPS. Selain itu, belum ada media pembelajaran yang efektif, minat baca dan motivasi siswa untuk belajar materi IPS rendah.

Berdasarkan hasil penilaian harian dengan kompetensi dasar (KD) 3.2 yang berbunyi menganalisis bentuk-bentuk interaksi manusia dengan lingkungan dan pengaruhnya terhadap pembangunan sosial, budaya, dan ekonomi masyarakat Indonesia diperoleh bahwa dari 43 peserta didik kelas V SDN Kalidawir terdapat 26 atau $60 \%$ telah mencapai kriteria ketuntasan minimal (KKM). Sedangkan 17 atau $40 \%$ belum mencapai nilai KKM. Maka disimpulkan bahwa siswa kelas V SDN Kalidawir belum menyelesaikan kompetensi dasar 3.2 mata pelajaran IPS. Sesuai dengan pendapat Block dalam Handoyo (2015: 773) bahwa pembelajaran dengan tuntas siswa dapat menguasai secara tuntas pembelajaran sekitar 75\% - 90\% dari ajaran yang diberikan.

Berpikir kritis menjadi tujuan penting dalam penelitian ini. Pertama, berpikir kritis menjadi salah satu komponen pemberdayaan yang tertuang dalam amanat UU No.20 Th. 2003 tentang Sistem Pendidikan Nasional, yaitu terselengarannya pendidikan berorientasi pada pemberdayaan, kebudayaan, pembinaan karakter, kepribadian, dan kecakapan hidup. Kedua, minimnya kemampuan berpikir kritis peserta didik di sekolah dasar. Karena dasar-dasar berpikir dikuasai dengan baik hingga pendidikan berikutnya. Anak di sekolah dasar berada diantara usia 7 sampai 12 tahun, fungsi memori, imajinasi, dan pikiran mulai berkembang, anak mulai berpikir kritis (Djaali dalam Prayitno 2015:2). Menurut teori kognitif Piaget bahwa pemikiran anak usia sekolah dasar disebut pemikiran operasional konkret, yaitu suatu kondisi di mana anak tersebut siap memfungsikan pikirannya untuk berpikir secara logis tentang sesuatu yang konkrit atau nyata. Pada tahap ini anak dihadapkan pada permasalahan yang bersifat abstrak (lisan) tanpa objek nyata, sehingga ia akan mengalami kesulitan bahkan tidak mampu menyelesaikannya dengan baik (Bujuri, 2018).

Dalam menciptakan proses pembelajaran yang bermakna, guru harus memberikan gambaran yang konkrit tentang materi yang disajikan tanpa mengabaikan media pembelajaran. Media pembelajaran memberikan kontribusi positif dalam suatu proses belajar mengajar. Pembelajaran dengan menggunakan media yang tepat memberikan hasil yang optimal bagi pemahaman siswa (Sundayana, 2016:3). Supriono dalam Rosidah (2016) berpendapat media pembelajaran mampu mengembangkan sikap, pengetahuan, dan keterampilan. Salah satu kunci keberhasilan pembelajaran yaitu adanya perubahan dari aspek kognitif, afektif, dan psikomotorik (Suryani, 2018:47).

Media pembelajaran sangat penting dalam melatih keterampilan berpikir kritis siswa (Subekti, 2018:74). Media pembelajaran dapat menjadikan pembelajaran lebih menarik, sehingga dapat menumbuhkan motivasi dan meningkatkan hasil belajar peserta didik (Sudjana dalam Wicaksono, 217: 114). Media pembelajaran memuat informasi dan pengetahuan yang digunakan untuk membuat proses belajar menjadi lebih efektif dan efisien, berisi informasi dan pengetahuan yang akan membuat proses pembelajaran menjadi lebih efektif dan efisien (Pribadi, 2017:13). 
Pelaksanaan pembelajaran di kelas, guru dapat menggunakan berbagai media pembelajaran yang dapat membantu kelancaran proses pembelajaran hingga tujuan pembelajaran dapat tercapai dengan baik. Masing-masing media memiliki kelebihan dan kekurangan dalam penggunannya, maka perlu memilih dengan cermat agar dapat digunakan secara tepat. Keadaan yang terjadi saat ini siswa kurang berminat membaca buku teks pelajaran, apalagi buku yang minim gambar dan kurang ilustrasi yang menarik, lebih menekankan sajian materi ajar dengan cakupan luas dan umum sehingga proses komunikasi berlangsung satu arah sehingga pembacanya cenderung pasif.

Arsyad(2014) menjelaskan bahwa media berbasis visual memiliki peran penting untuk menumbuhkan minat siswa dan memberi hubungan antara isi dengan dunia nyata, serta ditempatkan pada konteks yang bermakna sehingga siswa dapat berinteraksi dengan visual untuk meyakinkan terjadinya prosesya informasi agar menjadi efektif. Media komunikasi visual dan lebih daripada sekedar cerita bergambar yang ringan dan menghibur adalah komik (Lanti, 2017:53). Menurut Saputra (2016) komik merupakan media yang digunakan oleh guru untuk menyampaikan materi pembelajaran, melatih siswa memahami dialog, dan menganalisis suatu masalah.

Kekuatan pesan yang dimunculkan pada media komik tidak dapat diragukan lagi. Komik memiliki kelebihan dibandingkan dengan media lain antara lain meningkatkan minat baca anak, memperkaya kecerdasan visual dan dapat mendorong peserta didik untuk mengetahui peristiwa yang digambarkan dalam cerita. Komik berperan positif dalam mengembangkan kebiasaan membaca, komik dapat membantu siswa dalam memahami informasi. (Hamidah dalam Ridha, 2017). Peran komik dalam pembelajaran berada pada posisi untuk memperluas minat belajar siswa (Sudjana \& Rivai, 2011:68).

Permendiknas nomor 2 tahun 2008 pasal 6 ayat bahwa selain buku teks pelajaran. Guru dapat menggunakan buku panduan pendidik, buku pengayaan, buku referensi yang digunakan dalam proses pembelajaran. Buku pengayaan berupa komik difungsikan sebagai buku pendamping buku mata pelajaran dari pemerintah. Materi disesuaikan dengan gaya pengajaran sekolah, disajikan dalam bentuk narasi, dialog, maupun kombinasi dari berbagai model, isinya lebih terkini dibandingkan buku mata pelajaran atau buku teks. Komik itu sendiri bisa berupa ragam kesenian yang menggunakan gambar-gambar tidak bergerak yang kemudian disusun sedemikian rupa dalam sebuah alur cerita (Al-Maqassary dalam Ridha, 2017). Reilly dalam Nida menyatakan (2017) bahwa media komik membuat siswa lebih tertantang dalam mengerjakan tugas dan menggunakan kemampuan berpikir kritis dengan menganalisis cerita dan seni. Jadi dengan menganalisis cerita yang ada di komik siswa diharapkan dapat memiliki budaya pola berpikir kritis.

Beberapa penelitian terkait penggunaan komik untuk meningkatkan keterampilan berpikir kritis siswa yaitu penelitian yang dilakukan oleh Yonanda, et al (2019) dengan mengembangkan buku komik berbasis masalah sebagai media pembelajaran untuk meningkatkan kemampuan berpikir kritis siswa kelas IV sekolah dasar. Selain itu, penelitian yang dilakukan oleh Saputra (2016) telah berhasil meningkatkan berpikir kritis siswa sekolah dasar dengan menggunakan media komik islami. Implikasi komik dari berbagai penelitian dalam pengunaannya sebagai media pembelajaran sangat baik dan fleksibel.

Dalam penelitian ini akan mengembangkan buku komik sebagai media pembelajaran IPS siswa kelas V sekolah dasar. Materi instruksional yang dikembangkan berdasarkan kompetensi dasar 3.2 menganalisis bentuk-bentuk interaksi manusia dengan lingkungan dan pengaruhnya terhadap pembangunan sosial, budaya, dan ekonomi masyarakat Indonesia yang terdapat pada tema 3 yaitu makanan sehat, sub tema 1 bagaimana tubuh mengolah makanan, dan pembelajaran 3 . Penggunaan media dalam proses pembelajaran daring disediakan beberapa file berupa buku cetak, file $p d f$, dan flip book agar siswa dapat mengasesnya sesuai dengan kemampuan. Diharapkan pembelajaran berlangsung aktif, kreatif, dan menyenangkan meskipun dalam masa 
pandemi covid-19. Selain itu, untuk memenuhi pembelajaran abad 21 berbasis informasi dan teknologi. Komik tentang materi interaksi manusia dengan lingkungan diharapkan mampu membantu mencapai tujuan pembelajaran yaitu meningkatkan keterampilan berpikir kritis siswa.

Berdasarkan permasalahan di atas, peneliti tertarik untuk mengembangkan buku nonteks jenis pengayaan pengetahuan yang tampil dalam bentuk buku komik. Buku komik yang akan dikembangkan sesuai dengan kompetensi dasar. Materi buku bersifat kontekstual, dikaitkan dengan local content dan isu-isu penting dan masalah sosial yang dekat dengan lingkungan siswa dalam mendalami konsep dan materi IPS. Diharapkan setelah mempelajari materi tersebut siswa mampu menganalisis segala permasalahan sosial dan menghubungkan dengan pengalaman yang dimiliki dalam mengambil keputusan untuk menjelaskan kebenaran informasi. Maka inilah yang membedakan dengan penelitian-penelitian sebelumnya. Berdasarkan pernyataan di atas, peneliti akan melakukan penelitian dan pengembangan yang berjudul "Pengembangan Media Komik tentang Interaksi Manusia dengan Lingkungan untuk Meningkatkan Kemampuan Berpikir Kritis Siswa Kelas V Sekolah Dasar.

\section{KAJIAN TEORETIS Media Komik}

Kegiatan pembelajaran akan berlangsung maksimal jika guru mampu menciptakan proses pembelajaran yang bermutu, relevan, dan sesuai dengan kebutuhan anak. Dalam situasi Pembelajaran jarak Jauh (PJJ) saat ini peran media sangat dibutuhkan untuk menyampaikan informasi dan pengetahuan kepada siswa. Media berasal dari bahasa latin yaitu medium yang memiliki makna perantara atau pengantar. Oleh karena itu media diartikan sebagai perantara antara pengirim pengetahuan yang berfungsi sebagai sumber dan penerima informasi, Pribadi (2017:15). Media adalah segala bentuk sebagai penyalur informasi dari sumber pesan kepada penerima untuk merangsang pikiran, semangat, perhatian, dan kemauan dalam memperoleh pengetahuan, keterampilan, dan sikap sesuai dengan maksud disampaikannya informasi (Suryani, 2018:3)
Komik merupakan salah satu media komunikasi yang sangat diminati oleh semua lapisan masyarakat baik anak-anak, remaja, dan dewasa, (Ariyanto, 2017). Laksana (2015) menjelaskan komik merupakan jenis bacaan yang digemari oleh semua kalangan mulai anak-anak sampai orang dewasa karena penyajiannya berupa gambar, cerita, dan karakter tokoh menarik. Sedangkan menurut Rosyada (2012:100) komik dapat dijadikan sebagai media pembelajaran dimana gambarnya berbentuk (berkarakter), penyajiannya sederhana, memiliki alur cerita, mudah dipahami dan dengan bahasa verbal yang dialogis. Komik adalah representasi dari lisan dalam tulisan, diungkapkan dengan menggunakan elemen karakteristik seperti garis besar balon yang menunjukkan intonasi suara, bentuk huruf yang menunjukkan perasaan dan tindakan.

Menurut Laksana (2015: 153) manfaat komik yaitu penyampaian pesan dalam berbagai pengetahuan karena desainnya yang menarik, formatnya menggambarkan sesuatu yang berharga. Komik adalah suatu bacaan yang menarik dimana siswa membaca tanpa harus dibujuk, terdapat karakter, sehingga peserta didik mudah mengenal dan mengingat karakter tokoh-tokohnya. Guru dapat menumbuhkan minat baca siswa melalui media komik. Menurut Waluyanto (dalam Widyanti, 2015) media komik merupakan media visual yang dapat membantu menyampaikan informasi aktual dan lebih mudah dipahami karena berupa rangkaian gambar dan alur cerita. Dengan demikian, komik dibentuk dari rangkaian gambar, setiap panel dibuat dan dipisahkan oleh sebuah gang yang merupakan cerita yang koheren. Gambar tersebut biasanya dilengkapi dengan balon kata berisi sapaan yang disampaikan oleh tokoh, terkadang disertai narasi sebagai penjelasan dalam bentuk kotak dan dihubungkan pada tepi panel, sehingga menarik dan mudah dipahami isinya.

\section{Kemampuan Berpikir Kritis}

Berpikir kritis merupakan proses integrasi pengalaman pribadi, pelatihan, kemampuan, disertai alasan dalam mengambil keputusan untuk menjelaskan kebenaran informasi (Lismaya, 2019:10). Selain itu, Ennis (1962) mengemukakan bahwa critical thinking is reasonable and reflective 
thinking focused deciding what to believe or do" yaitu berpikir kritis merupakan proses berpikir reflektif yang berpusat pada sesuatu yang diyakini dan dilakukan.

Berpikir kritis bertujuan untuk mempertahankan posisi objektif artinya saat berpikir kritis seseorang akan mempertimbangkan sebuah argumen kemudian mengevaluasi kekuatan dan kelemahannya (Keynes dalam Zakiyah, 2019:5). Beberapa manfaat berpikir kritis antara lain: 1) mengenali potensi dan melatih mengembangkannya, 2) berpikir dan bertindak secara terampil, 3) memberikan solusi terbaik pada suatu masalah, 4) kemampuan berargumentasi baik dan komitmen, 5) fokus pada permasalahan dan fasih dalam menyelesaikannya sampai selesai, 6) keterampilan berbicara dan menulis logis dan analitis, dan 7) menelaah topik penting dan fokus terhadap suatu masalah, Subekti (2018: 20).

Ennis dalam Zubaidah (2010: 5), menjelaskan indikator berpikir kritis dikelompokkan ke dalam lima kegiatan besar dimana dalam praktiknya dapat dipadukan membentuk suatu kegiatan atau terpisah hanya beberapa indikator antara lain: 1) memberikan penjelasan yang sederhana yaitu memfokuskan pertanyaan, menganalisis pertanyaan, bertanya, dan menjawab pertanyaan, 2) mengembangkan keterampilan dasar dengan menganalisa sumber yang didapat akurat atau tidak, mengamati, mengkaji ulang laporan hasil pengamatan, 3) kesimpulan meliputi aktivitas menyimpulkan, menginduksi, menganalisis hasil deduksi atau induksi, membuat dan menentukan hasil pertimbangan, 4) menyajikan penjelasan lebih lanjut diantaranya mengidentifikasi istilah, definisi, dimensi, dan identifikasi hipotesis, 5) mengatur strategi dan teknik tentang tindakan yang akan dilakukan dan interaksi dengan lainnya.

Keterampilan berpikir kritis siswa dapat diukur melalui tes uji kompetensi berupa merespon jawaban dengan menjawab pertanyaan yang berbentuk esay. Pertanyaan berbentuk esay sifatnya terbuka berorientasi pada proses dan mengundang berbagai alternatif jawaban menurut pemahaman yang diperoleh siswa setelah membaca komik. Pemilihan tipe pertanyaan menentukan respon proses dan berpikir siswa untuk menentukan jawabannya. Dalam proses pembelajaran penggunaan teknik bertanya sebaiknya berdampak pada pengembangan keterampilan proses bukan sekedar terhadap ingatan siswa. Pertanyaan dikatakan baik jika mengandung jawaban yang terkait isu penting serta menuntut proses berpikir (Bima dalam Subekti, 2018:83).

\section{METODE PENELITIAN}

Penelitian ini merupakan jenis penelitian dan pengembangan atau Research and Development (R\&D). Menurut Sugiyono (2019:394) metode penelitian dan pengembangan merupakan metode penelitian yang digunakan untuk mengembangkan dan memvalidasi sebuah produk. Sejalan dengan pendapat Sukmadinata (2013:164) penelitian pengembangan adalah proses yang digunakan untuk mengembangkan dan menyempurnakan suatu produk yang dapat dipertanggungjawabkan setelah dilakukan uji validasi dan uji efektifitas. Penelitian ini menghasilkan sebuah produk pengembangan berupa media komik materi interaksi manusia dengan lingkungan pada tingkat kelas tinggi khususnya siswa kelas V sekolah dasar.

Prosedur pengembangan dalam penelitian ini menggunakan model pengembangan 4-D (Four-D Model). Model ini digunakan untuk mengembangkan perangkat pembelajaran yang dikembangkan oleh Thiagarajan, Semmel dan Semmel pada tahun 1974. Model penelitian dan pengembangan model 4D terdiri dari 4 tahapan, yaitu; define, design, develop, dan disseminate. Model 4D kemudian dapat diadaptasi menjadi 4P yaitu: pendefinisian, perancangan, pengembangan, dan penyebaran.

Prosedur penelitian pengembangan 4D secara umum memiliki tujuan mengembangkan produk yang memiliki fungsi dan menguji keefektifan produk melalui proses validasi. Langkah-langkah model pengembangan 4D yaitu 1) Tahap Define (pendefinisian), tahap ini digunakan untuk melihat jenis kebutuhan dalam proses pembelajaran dan mengumpulkan berbagai informasi terkait dengan produk komik yang akan dikembangkan. Tahap pendefinisian atau Analisa kebutuhan dapat dilakukan dnegan Analisa 
terhadap penelitian terdahulu dan studi literatur yang meliputi Front-end Analysis, Learner Analysis, Task Analysis, Concept Analysis, Specifying Instructional Objectives; 2) Tahap Design (perancangan), tahap perancangan dilakukan setelah memperoleh permasalahan dari tahap pendefinisian. Ada empat langkah dalam tahap perancangan ini antara lain yaitu Constructing Criterion-Referenced Test, Media Selection (Pemilihan Media), Format Selection (Pemilihan Format), Initial Design (Rancangan Awal); 3) Tahap Develop (pengembangan), tahapan ini bertujuan untuk mengevaluasi media komik yang sudah disusun untuk mendapatkan saran dan masukan dari ahli meteri dan media. Pada tahap ini dilakukan validasi untuk mengetahui kelayakan media yang diujicobakan. Tahap develop meliputi Expert Appraisal (Penilaian Ahli) dan Development Testing (Uji Coba Pengembangan); 4) Tahap Disseminate (Penyebarluasan), tahap penyebarluasan dilakukan untuk mempromosikan produk hasil pengembangan agar dapat dimanfaatkan secara efektif. Tahap disseminate melliputi Validation Testing, Packaging, Diffusion and adoption.

Subjek dalam penelitian ini adalah siswa kelas V di SDN Kalidawir Kecamatan Tanggulangin Kabupaten Sidoarjo. Penelitian dan pengembangan media ini dilaksanakan di SDN Kalidawir Kecamatan Tanggulangin Kabupaten Sidoarjo. Waktu pelaksanaan kegiatan penelitian dan pengembangan ini dilaksanakan pada semester 1 tahun pelajaran 2020-2021. Tema yang dikembangkan adalah tema 3, Sub Tema 1, Pembelajaran 3, materi tentang interaksi manusia dengan lingkungan. Adapun subyek penelitian ini adalah siswa kelas V SDN Kalidawir.

Data dikumpulkan menggunakan teknik pengumpulan data observasi, angket dan tes. Observasi digunakan untuk mengamati aktivitas guru dan siswa selama proses pembelajaran menggunakan media komik yang dikembangkan. Angket digunakan untuk melihat hasil validasi oleh ahli di bidangnya dan hasil respon siswa. Tes dalam penelitian ini terdiri dari ptretest dan postest untuk mengukur keterampilan berpikir kritis siswa. Lima aspek yang digunakan dalam penilaian keterampilan berpikir kritis yaitu keterampilan menganalisis, mensintesis, mengenal dan memecahkan masalah, menyimpulkan, dan mengevaluasi atau menilai

Analisis validasi yang dikembangkan dapat diperoleh dari nilai lembar instrumen validasi yang divalidasi oleh validator ahli materi dan ahli media. Validasi media komik terdiri dari validasi kelayakan materi, validasi bahasa, dan validasi kegrafikan.

$$
\text { Persentase }=\frac{\text { jumlah skor hasil validasi }}{\text { Jumlah skor tertinggi }} \times 100 \%
$$

(Riduwan, 2013:41)

Skor yang digunakan dalam penskoran lembar validasi yakni skala likert dengan tingkat jawaban mulai dari positif hingga negatif (Mawardi, 2019)

Tabel 1. Skala Likert

\begin{tabular}{cc}
\hline Skor & Keterangan \\
\hline 1 & Tidak baik \\
2 & Kurang baik \\
3 & Cukup baik \\
4 & Baik \\
5 & Sangat Baik \\
\hline
\end{tabular}

Data yang dihasilkan dari proses validasi berupa skor yang kemudian dilakukan perhitungan dengan rumus berikut ini:

$$
p \%=\frac{\text { jumlah skor hasil pengumpulan data }}{\text { skor maksimal }} \times 100 \%
$$

(Riduwan, 2013:41)
Media komik disebut layak apabila ratarata dari validasi media dan materi mendapatkan $\geq$ $61 \%$ dari tabel kriteria persentase kelayakan. Berikut ini tabel kriteria peesentase kelayakan. 
Tabel 2. Kriteria Persentase Validasi

\begin{tabular}{ccl}
\hline No. & Skor rata-rata & \multicolumn{1}{c}{ Kategori } \\
\hline 1. & $0 \%-20 \%$ & Sangat Kurang \\
2. & $21 \%-40 \%$ & Kurang \\
3. & $41 \%-70 \%$ & Cukup \\
4. & $71 \%-80 \%$ & Baik/ layak \\
5. & $81 \%-100 \%$ & Sangat Baik/ sangat Layak \\
\hline
\end{tabular}

(Riduwan, 2013:41)

Prosedur penganalisisan data uuntuk kualitas media komik meliputi observasi terhadap aktivitas pembelajaran yang dilakukan oleh guru dan siswa. Selain itu analisis hasil respon guru dan siswa dengan menggunakan lembar observasi atau angket berbentuk google form. Aktivitas guru dan siswa dapat diketahui dengan melakukan observasi aktivitas saat pembelajaran. Hasil observasi berupa skor dengan menggunakan skalai likert.

$\mathrm{P}(\%)=\frac{\sum K}{\sum N}$
Keterangan:

$\mathrm{P} \quad=$ Prosentase keterlaksanaan pembelajaran

$\sum K \quad=$ Frekuensi aspek yang dilakukan

$\sum N=$ Frekuensi keseluruhan komponen yang diamati

(Arikunto, 2013:18)

Hasil aktivitas pengamatan guru dan siswa kemudian ditransformasikan ke dalam pedoman pengamatan aktivitas pembelajaran sebagai berikut:

Tabel 3. Pedoman Pengamatan Kriteria Aktivitas Pembelajaran

\begin{tabular}{ccl}
\hline No. & Skor rata-rata & \multicolumn{1}{c}{ Kategori } \\
\hline 1. & $0 \%-20 \%$ & Sangat tidak aktif \\
2. & $21 \%-40 \%$ & Tidak aktif \\
3. & $41 \%-70 \%$ & Kurang aktif \\
4. & $71 \%-80 \%$ & Aktif \\
5. & $81 \%-100 \%$ & Sangat Aktif \\
\hline \multicolumn{2}{c}{ (Riduwan, 2013:41) }
\end{tabular}

Media komik dinyatakan praktis apabila rata-rata dari hasil pengamatan pelaksanaan pembelajaran mendapatkan $\geq 66 \%$ dari tabel kriteria persentase observasi. Sedangkan Analisis respon siswa terhadap penggunaan media komik menggunakan skala Guttman. Hasil kuesioner diperoleh melalui angket respon siswa terhadap media komik. Skala pengukuran menggunakan acuan skala Guttman sebagai berikut

\section{Tabel 4. Skala Penilaian Angket Siswa}

\begin{tabular}{cc}
\hline Jawaban & Skor \\
\hline Ya & 1 \\
Tidak & 0 \\
\hline
\end{tabular}

(Riduwan, 2013:44)

Setelah dilakukan pemberian angket kepada siswa, skor yang diperoleh dari kuesioner kemudian diolah menggunakan rumus di bawah ini.

$$
p \%=\frac{\text { jumlah skor hasil pengumpulan data }}{\text { skor maksimal }} \times 100 \%
$$

(Riduwan, 2013:41) 
Persentase angket peserta didik dimanfaatkan untuk mengetahui respon siswa dan guru terhadap media komik. Setelah hasil persentase diperoleh kemudian dilakukan interpretasi sesuai tabel berikut ini.

Tabel 6. Kriteria Persentase Angket Siswa

\begin{tabular}{ccc}
\hline No. & Skor rata-rata & Kategori \\
\hline 1. & $0 \%-20 \%$ & Sangat Kurang \\
2. & $21 \%-40 \%$ & Kurang \\
3. & $41 \%-70 \%$ & Cukup \\
4. & $71 \%-80 \%$ & Baik/ Layak \\
5. & $81 \%-100 \%$ & Sangat Baik/ Sangat Layak \\
\hline \multicolumn{2}{c}{ (Riduwan, 2013:41) }
\end{tabular}

Media komik dinyatakan efektif apabila rata-rata dari hasil angket atau kuesioner tanggapan penggunaan media mendapatkan $\geq 61$ dari tabel kriteria respon guru dan siswa.

Analisis aspek keefektifan media komik ditentukan berdasarkan hasil uji keterampilan berpikir kritis siswa. Teknik perhitungan menggunaklan dekripstif kuantitatif yaitu dengan mengukur ketuntasan hasil uji keterampilan siswa secara individual dengan nilai KKM 75 kemudian ketuntasan secara klasikal. Rumus yang digunakan untuk menghitung nilai siswa sebagai berikut:

Nilai Akhir $=\frac{\text { Skor yang diperoleh siswa }}{\text { Skor maksimal }} \times 100$

Selanjutnya menghitung ketuntasan uji keterampilan berpikir kritis secara klasikal dimana siswa dinyatakan tuntas jika perolehan nilai $>80 \%$ dan dianalisis dengan menggunakan rumus:

Ketuntasan klasikal $=\frac{\text { Jumlah } \text { siswa } \text { yang tuntas }}{\text { Jumlah } \text { seluruh } \text { siswa }} \times 100 \%$

Tabel 7. Kategori Ketuntasan Hasil Keterampilan Berpikir Kritis

\begin{tabular}{cc}
\hline Persentase & Kriteria \\
\hline$>75 \%$ & Sangat tinggi \\
$70 \%-75 \%$ & Tinggi \\
$55 \%-69 \%$ & Sedang \\
$20 \%-55 \%$ & Rendah \\
$<20 \%$ & Sangat rendah \\
\hline
\end{tabular}

(Aqib, dkk, 2015:41)

Analisis data keefektifan penggunaan produk komik berupa data kuantitatif dengan desain one group pre test - post test design. Desain ini digambarkan dengan pola berikut.

O1 X O 2

Keterangan:

$\mathrm{O} 1=$ nilai pretest

$\mathrm{X}=$ treatmen yang diberikan

$\mathrm{O} 2=$ nilai posttest

(Sugiyono, 2018:112)

Sebelum perlakuan diberikan pretest agar diketahui hasilnya lebih akurat dan dapat membandingkan kondisinya sebelum diberikan perlakuan (tetapi bukan kelas kontrol). Nilai pretest adalah hasil kemampuan keterampilan berpikir kritis siswa kelas V SDN Kalidawir sebelum menggunakan media komik. Sedangkan nilai posttest merupakan hasil kemampuan keterampilan berpikir kritis siswa setelah menggunakan media komik.

Perbedaan sebelum menggunakan media dan sesudah menggunakan media dapat diketahui dengan mengolah data menggunakan rata-rata (mean) dan t-test menggunakan SPSS versi 22. Hasil t-test disebut dengan t-hitung. Setelah thitung ditemukan kemudian dibandingkan dengan t-teoritik. T-teoritik didapatkan dengan cara menghitung $\mathrm{db}=\mathrm{N}-1$ dan melihat tabel nilai $\mathrm{t}$. Pada tabel nilai t digunakan taraf signifikan 5\% yang berarti kesalahan uji coba sebesar 5\% dan kebenaran uji coba sebesar $95 \%$. Jika didapatkan hasil perbandingan t-hitung dan t-teoritik 
menyatakan t-hitung $\geq \mathrm{t}$-tabel, maka penggunaan media setelah pembelajaran mengalami peningkatan daripada sebelum menngunakan media, sedangkan jika t-hitung $\leq \mathrm{t}$-tabel, maka penggunan media mengalami penurunan daripada sebelum menggunakan media.

\section{HASIL DAN PEMBAHASAN}

Sebelum digunakan untuk penelitian, media komik yang dikembangkan beserta perangkat pembelajaran dilakukan validasi terlebih dahulu. Adapun komponen-komponen perangkat pembelajaran yang diuji validasikan terlebih dahulu seperti, Rencana Pelaksanaan pembelajaran (RPP), Lembar Kegiatan Peserta Didik (LKPD), lembar validasi kemampuan berpikir kritis dan media komik. Berikut hasil validasi yang dinilai oleh Ahli di bidangnya sebagai berikut.

Tabel 8. Hasil Validasi Instrumen Penelitian oleh Ahli

\begin{tabular}{|c|c|c|c|}
\hline No. & Instrumen yang divalidiasi & $\begin{array}{c}\text { Rata-Rata } \\
\text { Persentase } \\
(\%)\end{array}$ & Kategori \\
\hline 1. & Media Komik komponen Materi & $79 \%$ & Layak \\
\hline 2. & $\begin{array}{l}\text { Media Komik komponen } \\
\text { Kebahasaan }\end{array}$ & $81 \%$ & $\begin{array}{l}\text { Sangat } \\
\text { Layak }\end{array}$ \\
\hline 3 & $\begin{array}{l}\text { Media Komik komponen } \\
\text { Kegrafikan }\end{array}$ & $86 \%$ & $\begin{array}{l}\text { Sangat } \\
\text { Layak }\end{array}$ \\
\hline 4. & Rencana Pelaksanaan Pembelajaran & $85 \%$ & $\begin{array}{l}\text { Sangat } \\
\text { Layak }\end{array}$ \\
\hline 5. & Lembar observasi guru & $88 \%$ & $\begin{array}{l}\text { Sangat } \\
\text { Layak }\end{array}$ \\
\hline 6. & Lembar observasi siswa & $88 \%$ & $\begin{array}{l}\text { Sangat } \\
\text { Layak }\end{array}$ \\
\hline 7. & Lembar angket respon siswa & $91 \%$ & $\begin{array}{l}\text { Sangat } \\
\text { Layak }\end{array}$ \\
\hline 8. & Tes Berpikir Kritis & $85 \%$ & $\begin{array}{l}\text { Sangat } \\
\text { Layak }\end{array}$ \\
\hline
\end{tabular}

Berdasarkan tabel di atas, dapat diketahui bahwa keseluruhan aspek yang divalidasi oleh validator mendapatkan skor rata-rata persentase sangat layak. Dengan demikian, media komik yang dikembangkan beserta instrumen perangkat pembelajaran telah memenuhi kriteria kelayakan dan dapat digunakan untuk melakukan penelitian.

Kevalidan terhadap kelayakan media pembelajaran yang dikembangkan dilakukan untuk mengetahui tingkat kelayakan dari media komik. Kualitas dari aspek media ini divalidkan oleh beberapa ahli yaitu ahli materi menvalidkan materi dan ahli media memvalidkan kualitas media. Berdasarkan hasil kevalidan draf I, terdapat beberapa skor pada instrumen kevalidan yang harus diperbaiki sesuai dengan saran validator/ahli. Kemudian, berdasarkan saran dari validator ada juga beberapa aspek dalam instrumen yang dilakukan perbaikan. Hasil revisi tersebut menghasilkan draf II dan semua validator menyatakan media layak untuk digunakan. Validasi media komik digital dilakukan terlebih dahulu kepada ahli materi dan kemudian ahli media. Penilai kelayakan media dari segi materi dilakukan melalui proses validasi oleh ahli materi. Sedangkan penilaian kelayakan media dari aspek isi dan tujuan, bahasa, grafik serta penyajian melalui proses validasi oleh ahli media.

Hasil validasi media komik oleh validator ahli komponen materi memperoleh skor sebesar 31.5 dari skor maksimal sebesar 40, sehingga sebanding dengan $79 \%$ dalam kriteria sangat layak. Komponen kebahasaan memperoleh skor sebesar 26 dari skor maksimal sebesar 32, sehingga sebanding dengan $81 \%$ dalam kriteria sangat layak. Sedangkan komponen kegrafikan memperoleh skor sebesar 34.5 dari skor maksimal sebesar 40 , 
sehingga sebanding dengan $86 \%$ dalam kriteria sangat layak.

Ukuran sebuah produk dapat dikatakan berkualitas jika telah memenuhi beberapa aspek kualitas produk, Produk yang dikembangkan dalam penelitian pengembangan ini berdasarkan uji validasi validator ahli telah menunjukkan bahwa semua aspek yang diuji memiliki skor kevalidan produk Sangat Baik (SB). Pernyataan tersebut sesuai dengan pendapat yang dikemukakan Nieveen (1999:123) bahwa suatu produk dapat dikatakan berkualitas apabila memenuhi aspek-aspek kualitas produk antara lain (1) kevalidan (validity); (2) kepraktisan (practicy); (3) keefektifan (effectiveness).

Penilaian observasi aktivitas guru menggunakan skala likert berdasarkan lembar observasi aktivitas guru yang diamati oleh dua observer. Berikut disajikan hasil rata-rata observasi aktivitas guru disajikan pada tabel di bawah ini.

Tabel 9. Rekapitulasi Hasil Observasi Aktivitas Guru

\begin{tabular}{lcccc}
\hline \multicolumn{1}{c}{ Aspek Aktivitas Guru } & O1 & O2 & Persentase & Keterangan \\
\hline Pertemuan I & 3.25 & 3.15 & $80 \%$ & aktif \\
Pertemuan II & 3.75 & 3.8 & $94 \%$ & sangat aktif \\
\hline \multicolumn{2}{l}{ Keterangan: O1 = Observer 1; O2 = Observer 2 }
\end{tabular}

Selanjutnya, penilaian observasi aktivitas siswa menggunakan skala likert berdasarkan lembar observasi aktivitas siswayang diamati oleh dua observer. Berikut disajikan hasil rata-rata observasi aktivitas siswa disajikan pada tabel di bawah ini.

Tabel 10. Rekapitulasi Hasil Observasi Aktivitas Siswa

\begin{tabular}{lcccc}
\hline \multicolumn{1}{c}{ Aspek Aktivitas Siswa } & O1 & O2 & Persentase & Keterangan \\
\hline Pertemuan I & 3.1 & 3.1 & $78 \%$ & aktif \\
Pertemuan II & 3.8 & 3.8 & $95 \%$ & sangat aktif \\
\hline
\end{tabular}

Keterangan: $\mathrm{O} 1=$ Observer $1 ; \mathrm{O} 2=$ Observer 2

Diperoleh data hasil dari angket respon siswa yang diberikan sesuai siswa melaksanakan kegiatan pembelajaran pada uji coba pada 43 siswa. Adapun hasil respon siswa terhadap media komik materi interaksi manusia dengan lingkungannya untuk meningkatkan berpikir kritis siswa kelas $\mathrm{V}$ sekolah dasar dipaparkan pada tabel 11.

Tabel 11. Hasil Respon Siswa Terhadap Media Komik

\begin{tabular}{|c|c|c|c|c|c|c|}
\hline \multirow[t]{2}{*}{ No } & \multirow[t]{2}{*}{ Pernyataan } & \multicolumn{2}{|c|}{$\begin{array}{l}\text { Jawaban } \\
\text { Siswa }\end{array}$} & \multicolumn{2}{|c|}{ Persentase } & \multirow[t]{2}{*}{ Kriteria } \\
\hline & & $\mathbf{Y a}$ & Tidak & Ya & Tidak & \\
\hline 1 & $\begin{array}{l}\text { Apakah warna, tulisan, dan } \\
\text { gambar dalam komik sangat } \\
\text { menarik? }\end{array}$ & 43 & 0 & $\begin{array}{c}100 \\
\%\end{array}$ & $0 \%$ & $\begin{array}{l}\text { sangat } \\
\text { baik }\end{array}$ \\
\hline 2 & $\begin{array}{l}\text { Apakah tampilan gambar dan } \\
\text { teks sangat mendukung dalam } \\
\text { belajar }\end{array}$ & 41 & 2 & $95 \%$ & $5 \%$ & $\begin{array}{l}\text { sangat } \\
\text { baik }\end{array}$ \\
\hline 3 & $\begin{array}{l}\text { Apakah materi dalam komik } \\
\text { menarik dan mudah dipahami }\end{array}$ & 40 & 3 & $93 \%$ & $7 \%$ & $\begin{array}{l}\text { sangat } \\
\text { baik }\end{array}$ \\
\hline 4 & $\begin{array}{l}\text { Apakah alur cerita dalam } \\
\text { komik mudah dipahami dan } \\
\text { menarik }\end{array}$ & 37 & 6 & $86 \%$ & $14 \%$ & $\begin{array}{l}\text { sangat } \\
\text { baik }\end{array}$ \\
\hline 5 & $\begin{array}{l}\text { Apakah kamu dapat } \\
\text { mengajukan pertanyaan kritis } \\
\text { setelah menggunakan komik }\end{array}$ & 38 & 5 & $88 \%$ & $12 \%$ & $\begin{array}{l}\text { sangat } \\
\text { baik }\end{array}$ \\
\hline
\end{tabular}




\begin{tabular}{|c|c|c|c|c|c|c|}
\hline 6 & $\begin{array}{l}\text { Apakah kamu mendapatkan } \\
\text { pengetahuan baru setelah } \\
\text { membaca komik }\end{array}$ & 40 & 3 & $93 \%$ & $7 \%$ & $\begin{array}{l}\text { sangat } \\
\text { baik }\end{array}$ \\
\hline 7 & $\begin{array}{lrr}\text { Apakah bahasa } & \text { yang } \\
\text { digunakan dalam } & \text { komik } \\
\text { mudah dipahami? } & \end{array}$ & 39 & 4 & $91 \%$ & $9 \%$ & $\begin{array}{l}\text { sangat } \\
\text { baik }\end{array}$ \\
\hline 8 & $\begin{array}{l}\text { Apakah gambar terlihat jelas } \\
\text { dan menarik? }\end{array}$ & 43 & 0 & $\begin{array}{c}100 \\
\%\end{array}$ & $0 \%$ & $\begin{array}{c}\text { sangat } \\
\text { baik }\end{array}$ \\
\hline 9 & $\begin{array}{l}\text { Dialog dalam komik mudah } \\
\text { dipahami }\end{array}$ & 39 & 4 & $91 \%$ & $9 \%$ & $\begin{array}{l}\text { sangat } \\
\text { baik }\end{array}$ \\
\hline 10 & $\begin{array}{l}\text { Halaman urut sesuai dengan } \\
\text { alur cerita }\end{array}$ & 38 & 5 & $88 \%$ & $12 \%$ & $\begin{array}{c}\text { sangat } \\
\text { baik }\end{array}$ \\
\hline 11 & $\begin{array}{l}\text { Apakah media komik mudah } \\
\text { digunakan } \\
\text { pembelajaran? }\end{array}$ & 40 & 3 & $93 \%$ & $7 \%$ & $\begin{array}{l}\text { sangat } \\
\text { baik }\end{array}$ \\
\hline 12 & $\begin{array}{l}\text { Ukuran gambar komik sudah } \\
\text { sesuai }\end{array}$ & 40 & 3 & $93 \%$ & $7 \%$ & $\begin{array}{c}\text { sangat } \\
\text { baik }\end{array}$ \\
\hline 13 & $\begin{array}{l}\text { Apakah kamu menyukai } \\
\text { karakter yang dibawakan } \\
\text { dalam komik? }\end{array}$ & 43 & 0 & $\begin{array}{c}100 \\
\%\end{array}$ & $0 \%$ & $\begin{array}{l}\text { sangat } \\
\text { baik }\end{array}$ \\
\hline 14 & Ilustrasi komik menarik & 40 & 3 & $93 \%$ & $7 \%$ & $\begin{array}{l}\text { sangat } \\
\text { baik }\end{array}$ \\
\hline 15 & $\begin{array}{l}\text { Apakah gambar dalam komik } \\
\text { menarik? }\end{array}$ & 42 & 1 & $98 \%$ & $2 \%$ & $\begin{array}{l}\text { sangat } \\
\text { baik }\end{array}$ \\
\hline 16 & $\begin{array}{l}\text { Apakah model huruf terbaca } \\
\text { jelas dan menarik? }\end{array}$ & 39 & 4 & $91 \%$ & $9 \%$ & $\begin{array}{l}\text { sangat } \\
\text { baik }\end{array}$ \\
\hline 17 & $\begin{array}{l}\text { Warna halaman komik sesuai } \\
\text { dan menarik }\end{array}$ & 40 & 3 & $93 \%$ & $7 \%$ & $\begin{array}{l}\text { sangat } \\
\text { baik }\end{array}$ \\
\hline & Rata-Rata Keseluruhan & & & $93 \%$ & $7 \%$ & $\begin{array}{c}\text { Sangat } \\
\text { baik }\end{array}$ \\
\hline
\end{tabular}

Berdasarkan Tabel 11 menjelaskan bahwa respon siswa terhadap media komik yang dikembangkan didapat data seperti diatas dengan rincian presentase menjawab "ya" antara $85 \%$ $100 \%$ dan menjawab "tidak" antara $0 \%-15 \%$.

Produk dapat dikatakan praktis apabila memudahkan pengguna untuk memakai atau menggunakan produk. Produk yang dihasilkan dalam penelitian pengembangan ini dilakukan uji coba untuk mengetahui tingkat kepraktisan sebuah produk. Hasil uji coba dapat diketahui dari hasil observasi 2 pengamat dan angket.

Hasil observasi aktivitas guru pada pertemuan I memperoleh persentase $80 \%$ dengan kriteria aktif dan pada pertemuan II memperoleh persentase 94\% dengan kriteria sangat aktif. Sedangkan hasil observasi aktivitas siswa pertemuan I memperoleh persentase $78 \%$ dengan kriteria aktif dan pertemuan II memperoleh persentase 95\% dengan kriteria sangat aktif. Hasil rekapitulasi respon angket siswa pada uji coba lapangan sejumlah 43 siswa terhadap penggunaan media komik materi interaksi manusia dengan lingkungannya memperoleh persentase $93 \%$ siswa yang menjawab "ya". Hasil persentase sebesar 93\% dapat dikategorikan dalam kualifikasi sangat baik berdasarkan acuan skala Guttman dalam penentuan kriteria penelitian ini.

Keefektifan media komik yang dikembangkan peneliti dapat dilihat dari tes keterampilan berpikir kritis setelah mengikuti pembelajaran daring. Peserta didik mengerjakan tes berpikir kritis secara daring pada platform google form dan Ms. Teams. Untuk mengetahui hasil peningkatan berpikir kritis siswa, maka sebelum diberikan perlakuan siswa diberi soal pretest terlebih dulu dan setelah diberikan perilakuan siswa diberi soal posttest. Pretest diberikan di awal untuk mengetahui kemempuan awal siswa sedangkan untuk mengetahui peningkatan keterampilan berpikir kritis diberikan soal posttest yang diberikan setelah melakukan pembelajaran menggunakan media komik materi interkasi manusia dengan lingkungannya. Hasil dari pretest dan posttest keterampilan berpikir 
kritis siswa pada uji coba disajikan dalam tabel di bawah ini.

Tabel 12. Data Hasil Keterampilan Berpikir Kritis

\begin{tabular}{|c|c|c|c|c|c|c|c|}
\hline \multirow{2}{*}{ No. } & \multirow{2}{*}{ Nama } & \multicolumn{2}{|c|}{ Nilai } & \multicolumn{2}{|c|}{ Ketuntasa } & \multirow{2}{*}{$\begin{array}{l}\mathbf{N}- \\
\text { Gain }\end{array}$} & \multirow{2}{*}{ Keterangan } \\
\hline & & Pretest & Posttest & Pretest & Posttest & & \\
\hline 1 & AFA & 60 & 85 & TT & $\mathrm{T}$ & 0.63 & sedang \\
\hline 2 & $\mathrm{AR}$ & 65 & 80 & TT & $\mathrm{T}$ & 0.43 & sedang \\
\hline 3 & ARR & 70 & 85 & TT & $\mathrm{T}$ & 0.50 & sedang \\
\hline 4 & ATS & 55 & 75 & TT & $\mathrm{T}$ & 0.44 & sedang \\
\hline 5 & ARA & 60 & 75 & TT & $\mathrm{T}$ & 0.38 & sedang \\
\hline 6 & AFAN & 45 & 70 & TT & TT & 0.45 & sedang \\
\hline 7 & AAA & 55 & 80 & TT & $\mathrm{T}$ & 0.56 & sedang \\
\hline 8 & AHS & 65 & 90 & TT & $\mathrm{T}$ & 0.71 & tinggi \\
\hline 9 & APR & 75 & 90 & $\mathrm{~T}$ & $\mathrm{~T}$ & 0.60 & sedang \\
\hline 10 & AFR & 70 & 75 & TT & $\mathrm{T}$ & 0.17 & rendah \\
\hline 11 & AZR & 80 & 95 & $\mathrm{~T}$ & $\mathrm{~T}$ & 0.75 & tinggi \\
\hline 12 & $\mathrm{AZ}$ & 45 & 65 & TT & TT & 0.36 & sedang \\
\hline 13 & DP & 85 & 100 & $\mathrm{~T}$ & $\mathrm{~T}$ & 1.00 & tinggi \\
\hline 14 & DAN & 65 & 75 & TT & $\mathrm{T}$ & 0.29 & rendah \\
\hline 15 & HCWR & 80 & 95 & $\mathrm{~T}$ & $\mathrm{~T}$ & 0.75 & tinggi \\
\hline 16 & HAD & 45 & 60 & TT & TT & 0.27 & rendah \\
\hline 17 & INL & 80 & 90 & $\mathrm{~T}$ & $\mathrm{~T}$ & 0.50 & sedang \\
\hline 18 & MAAA & 50 & 70 & TT & TT & 0.40 & sedang \\
\hline 19 & MSR & 55 & 70 & TT & TT & 0.33 & sedang \\
\hline 20 & MKMP & 55 & 65 & TT & TT & 0.22 & rendah \\
\hline 21 & MRA & 70 & 85 & TT & $\mathrm{T}$ & 0.50 & sedang \\
\hline 22 & MRA & 75 & 85 & $\mathrm{~T}$ & $\mathrm{~T}$ & 0.40 & sedang \\
\hline 23 & MRA & 75 & 90 & $\mathrm{~T}$ & $\mathrm{~T}$ & 0.60 & sedang \\
\hline 24 & MFA & 70 & 80 & TT & $\mathrm{T}$ & 0.33 & sedang \\
\hline 25 & MIF & 60 & 80 & TT & $\mathrm{T}$ & 0.50 & sedang \\
\hline 26 & MNH & 80 & 95 & $\mathrm{~T}$ & $\mathrm{~T}$ & 0.75 & tinggi \\
\hline 27 & NZA & 85 & 100 & $\mathrm{~T}$ & $\mathrm{~T}$ & 1.00 & tinggi \\
\hline 28 & $\mathrm{NN}$ & 65 & 85 & TT & $\mathrm{T}$ & 0.57 & sedang \\
\hline 29 & NNA & 50 & 75 & TT & $\mathrm{T}$ & 0.50 & sedang \\
\hline 30 & PA & 65 & 75 & TT & $\mathrm{T}$ & 0.29 & rendah \\
\hline 31 & RHN & 85 & 95 & $\mathrm{~T}$ & $\mathrm{~T}$ & 0.67 & sedang \\
\hline 32 & RA & 60 & 85 & TT & $\mathrm{T}$ & 0.63 & sedang \\
\hline 33 & RLP & 50 & 80 & TT & $\mathrm{T}$ & 0.60 & sedang \\
\hline 34 & SNA & 60 & 80 & TT & $\mathrm{T}$ & 0.50 & sedang \\
\hline 35 & SCR & 50 & 75 & TT & $\mathrm{T}$ & 0.50 & sedang \\
\hline 36 & SPM & 50 & 75 & TT & $\mathrm{T}$ & 0.50 & sedang \\
\hline 37 & SK & 75 & 90 & $\mathrm{~T}$ & $\mathrm{~T}$ & 0.60 & sedang \\
\hline 38 & UMA & 55 & 80 & TT & $\mathrm{T}$ & 0.56 & sedang \\
\hline 39 & WQANR & 75 & 100 & $\mathrm{~T}$ & $\mathrm{~T}$ & 1.00 & tinggi \\
\hline 40 & ZKN & 60 & 80 & TT & $\mathrm{T}$ & 0.50 & sedang \\
\hline 41 & BZAF & 55 & 70 & TT & $\mathrm{TT}$ & 0.33 & sedang \\
\hline 42 & KSR & 75 & 95 & $\mathrm{~T}$ & $\mathrm{~T}$ & 0.80 & tinggi \\
\hline 43 & FYRZ & 60 & 75 & TT & $\mathrm{T}$ & 0.38 & sedang \\
\hline \multirow{2}{*}{\multicolumn{4}{|c|}{$\begin{array}{cc}\text { Rata-Rata } & 64.30 \\
\text { Jumlah Siswa yang Tuntas }\end{array}$}} & TT & $\mathbf{T}$ & 0.53 & sedang \\
\hline & & & & 13 & 36 & & \\
\hline \multicolumn{4}{|c|}{ Persentase Ketuntasan Klasikan } & $30 \%$ & $84 \%$ & & \\
\hline
\end{tabular}


Analisis data dalam penelitian ini menggunakan uji $\mathrm{t}$ dengan rumus paired t-test untuk mengetahui keefektifan dari media komik materi interaksi manusia dengan lingkungan yang dikembangkan. Analisis statistik termasuk uji statistik parametrik maka harus memenuhi uji prasyarat yaitu uji normalitas. Tingkat kesalahan (taraf signifikansi) yang digunakan dalam penelitian ini sebesar 0.05 . Uji prasyarat analisis ini bertujuan untuk mengetahui ada penyimpangan atau tidaknya terhadap variabel-variabel yang ada.
Berikut ini beberapa uji prayarat yang dilakukan yaitu sebagai berikut.

Uji normalitas dalam penelitian ini menggunakan shapiro-wilk. Untuk mengetahui normal tidaknya distribusi data dapat diketahui dari besarnya nilai shapiro-wilk pada setiap variabel yang diteliti. Kriteria pengujian apabila nilai $\mathrm{p} \geq$ 0.05 maka data berdistribusi normal. Sebaliknya apabila nilai $\mathrm{p} \leq 0.05$ maka data tidak berdistribusi normal. Hasil uji normalitas dari beberapa variabel dalam penelitian ini dapat dilihat dari tabel berikut.

Tabel 13. Hasil Uji Normalitas

\begin{tabular}{lccc}
\hline \multicolumn{1}{c}{ Tes } & $\begin{array}{c}\text { Signifikansi } \\
(\mathbf{p})\end{array}$ & Taraf $\mathbf{( 5 \% )}$ & Keterangan \\
\hline Pretest & 0.098 & 0.05 & Normal \\
Posttest & 0.066 & 0.05 & Normal \\
\hline
\end{tabular}

Berdasarkan tabel tersebut, hasil uji normalitas dapat dilihat bahwa nilai signifikansi untuk semua data pada setiap variabel dalam penelitian memperoleh nilai lebih besar dari 0.05 , maka semua data dinyatakan berdistribusi normal.

Setelah dilakukan uji prasyarat analisis yaitu uji normalitas, langkah selanjutnya yaitu melakukan analisis data. Teknik analisis data yang digunakan pada penelitian ini adalah uji paired $t$ test. Oleh karena pada tes pretest dan posttest memenuhi asumsi normalitas dan homogenitas, maka dilakukan uji $\mathrm{t}$ rumus paired t-test yang digunakan untuk mengetahui signifikansi dari produk yang telah dikembangkan. Adapun hasil penghitungannya sebagai berikut.

Tabel 14. Hasil Uji Keefektifan Media Komik

\begin{tabular}{ccc}
\hline $\mathbf{t}$ hitung & Sig. (p) & Keterangan \\
\hline 19.811 & 0.000 & $\begin{array}{c}\text { Ada perbedaan sebelum menggunakan } \\
\text { media komik (pretest) dan sesudah } \\
\text { menggunakan media komik (posttest) }\end{array}$ \\
\hline
\end{tabular}

Berdasarkan tabel 14 perhitungan menggunakan uji signifikansi untuk nilai keterampilan berpikir kritis siswa pada penelitian ini diperoleh $t_{\text {hitung }}$ sebesar 19.811 dengan signifikan sebesar 0.000. Jadi, dapat disimpulkan bahwa nilai signifikansi $(0.000)<0.05$. Dengan demikian, dapat dinyatakan bahwa terdapat perbedaan yang signifikan pada keterampilan berpikir kritis siswa kelas V sekolah dasar setelah menggunakan media komik materi interaksi manusia dengan lingkungan. Keefektifan produk dapat dilihat dari hasil pemberian tes yang diberikan kepada siswa, sehingga hasil belajar sangat penting untuk mengukur efektifan belajar. Hal tersebut sesuai dengan pernyataan (Purwanto,
2011: 38) yang menyatakan bahwa hasil belajar digunakan untuk mengetahui seberapa jauh seseorang menerima atau memahami bahan atau materi yang telah disampaikan. Pada penelitian dan pengembangan ini keefektifan dilihat dari hasil pemberian tes berkaitan penguatan pendidikan karakter siswa yang diberikan kepada siswa melalui pretest (sebelum dilakukan perlakukan) dan posttest (sesudah perlakuan) dengan menggunakan media komik digital.

Penggunaan media menjadi sarana belajar telah lama digunakan. Media yang berisi materi dan penjelasan dimanfaatkan dalam pembelajaran untuk menciptakan suasana efektif dan efisien (Pribadi, 2017). Media adalah segala bentuk 
sebagai penyalur informasi dari sumber pesan kepada penerima untuk merangsang pikiran, semangat, perhatian, dan kemauan dalam memperoleh pengetahuan, keterampilan, dan sikap sesuai dengan maksud disampaikannya informasi (Suryani, 2018:3). Selain itu, menurut Arsyad (2014:275) kegunaan media yaitu sebagai sarana dalam menciptakan pembelajaran yang mengaitkan mental dan aktivitas siswa, materi lebih sitematis, sesuai dengan prinsip-prinsip pembelajaran, sehingga pembelajaran menjadi bermakna dan sesuai kebutuhan siswa

Komik merupakan cerita bergambar disertai teks yang mampu menarik perhatian siswa untuk membacanya. Ekspresi yang divisualisasikan mampu membuat siswa untuk terus membaca hingga selesai. Komik merupakan media yang memiliki potensi positif dalam pembelajaran karena dapat meningkatkan motivasi belajar siswa (Widyanti, 2015). Komik mampu meningkatkan motivasi belajar siswa sehingga pada akhirnya mampu meningkatkan keterampilan berpikir kritis siswa. Adapun berpikir kritis dapat dibentuk dengan menggunakan logika secara rasional melalui pembuktian secara empiris tentang apa yang sedang dipelajari, (Musfiqon, 2015:65). Pembuktian empiris tersebut dilakukan melalui analisis tentang materi pelajaran yang menjadi dasar untuk menyimpulkan materi.

Dalam mengajarkan keterampilan berpikir kritis siswa pada muatan IPS yaitu dengan mengaitkan fakta, mengkonstruksikan fakta menjadi suatu gagasan yang melahirkan generalisasi. Generalisasi terkait untuk memberikan konstruksi. Dengan kebiasaan membangun konstruk peserta didik terampil mengamati masalah dan siap mencari alternatif pemecahan masalah, sehingga akan lebih siap menghadapi tantangan kehidupan yang lebih kompleks (Ulwiyah, 2014). Kemampuan menyelesaikan masalah membutuhkan keterampilan berpikir kritis. yaitu dengan memberikan pelatihan berpikir kritis melalui IPS diharapkan siswa mampu menghadapi konteks kehidupan yang lebih luas. Hal ini sesuai dengan pendapat Winataputra (2010: 7.11) bahwa mata pelajaran IPS bertujuan untuk membekali peserta didik agar mampu menghadapi dan memenuhi kompleksitas kehidupan masyarakat yang berkembang setiap saat dan tidak terduga.

Pemanfaatan media yang tepat dan variatif dapat mengatasi sikap pasif siswa yaitu menimbulkan semangat belajar, memungkinkan terjadinya interaksi langsung antara siswa dan juga lingkungan nyata, memungkinkan siswa belajar mandiri sesuai kemampuan dan minatnya (Sadiman, dkk. 2014:17). Media pembelajaran dapat merangsang proses berpikir kritis, analitis, kooperatif dan belajar mengambil keputusan. Siswa dapat dilatih untuk memiliki sikap percaya diri dalam beragumen, memiliki keyakinan yang tinggi, mempertahankan pendapatnya, dan menemukan konsep sendiri.

Pada komik disajikan materi intruksional dan disesuaikan dengan karakteristik siswa. Permasalahan yang disajikan lebih kompleks, tujuannya mengajarkan siswa agar dapat mendekomposisikan masalah tersebut. Pemikiran kritis dilatih dengan memanfaatkan sumber daya alam yang ada sehingga terbentuk life skill (kecakapan). Kecakapan di masa mendatang menuntut siswa mampu mengambil keputusan degan cepat dan tepat. Maka keterampilan berpikir tingkat tinggi yang dilatih disini yaitu siswa berani mengambil keputusan secara mandiri, siswa berani mencoba dan melakukan sesuatu dari hasil berpikir kritis. Jadi, bukan hanya teori tetapi bagaimana siswa dilatih untuk mampu mengeksplorasi terkait permasalahan tersebut.

Media komik yang dikembangkan oleh peneliti dapat mendukung fungsi media sebagai sumber belajar perantara dalam penyampaian infomasi dan pemahanan siswa. Sumber belajar mempunyai arti sebagai penyampai, penyalur, dan penghubung dengan demikian sumber belajar dapat dipahami oleh siswa yang mempermudahkan terjadinya proses. Media komik digital dalam pembelajaran IPS materi interaksi manusia dengan lingkungannya pada siswa kelas V Sekolah Dasar dapat memperkuat respon siswa untuk memahami suatu materi selain itu meningkatkan kualitas belajar siswa yang bersumber dari pengalaman sehingga menjadikan siswa lebih aktif dalam pembelajaran. Pernyataan oleh Mustaji (2013:9) media pembelajaran memiliki fungsi untuk menyederhanakan materi pembelajaran yang 
rumit, memperjelaskan suatu objek materi. Di sisi lain sebagai media untuk memperjelas dan memudahkan penyampaian materi, media komik digital dapat dijadikan media inovatif pada pembelajaran IPS yang bermakna dan meningkatkan antusiasme belajar dengan melibatkan siswa secara aktif.

Menurut Laksana (2015: 153) manfaat komik yaitu penyampaian pesan dalam berbagai pengetahuan karena desainnya yang menarik, formatnya menggambarkan sesuatu yang berharga, bukan sekedar hiburan. Komik adalah suatu bacaan yang menarik dimana siswa membaca tanpa harus dibujuk, terdapat karakter, sehingga peserta didik mudah mengenal dan mengingat karakter tokohtokohnya. Guru dapat menumbuhkan minat baca siswa melalui media komik. Media komik menurut Waluyanto dalam Widyanti (2015:25) merupakan media visual yang dapat membantu menyampaikan informasi aktual dan lebih mudah dipahami karena berupa rangkaian gambar dan alur cerita.

Proses pembelajaran selalu mengaitkan antara kompetensi pengetahuan dan kompetensi keterampilan, seperti yang dikemukakan oleh David Ausubel (1979) bahwa pembelajaran baru akan tersimpan dalam memori yang lama dan dijadikan pengetahuan baru jika terjadi interaksi antara subjek belajar (peserta didik) dan materi ajar (konsep) melalui kegiatan (keterampilan). Dalam penelitian ini menguji peserta didik di kelas V SD pada usia 10 - 11 tahun yang berada pada tahap operasional konkret. Menurut Piaget aktivitas berpikir anak pada tahap operasional konkret terfokus pada objek-objek peristiwa nyata atau konkret. Penggunaan media akan memberikan pengalaman belajar bagi anak. Seperti yang dikemukakan oleh Edgar Dale (1969), tingkatan pengalaman disajikan dalam bentuk kerucut pengalaman yang menggambarkan bahwa peserta didik dapat memperoleh pengalaman belajar yang lebih tepat melalui kegiatan melakukan sendiri apa yang ia pelajari, kegiatan mengamati, dan kegiatan mendengarkan dengan media tertentu. Dengan begitu guru harus dapat mengkonkretkan bahan ajar yang bersifat abstrak melalui media pembelajaran.

Dalam membaca komik terdapat hubungan antara kemampuan kognitif berpikir kritis dengan rasionalitas penggunaan komik dalam pembelajaran antara lain: interpretasi terjadi saat siswa memahami makna gambar dan teks dalam komik; analisis dilakukan saat siswa mengidentifikasi hubungan antara gambar dengan dialog pada komik; evaluasi dilakukan saat siswa menilai suatu pernyataan atau simpulan dalam komik; menyimpulkan terjadi saat siswa menarik kesimpulan mengenai isi komik baik dari segi cerita maupun konsep yang diajarkan; dan mengkreasikan Ketika siswa mampu mengeksplorasikan setelah memahami cerita dan konsep yang ada di komik.

Keterampilan berpikir kritis siswa dapat diukur melalui tes uji kompetensi berupa merespon jawaban dengan menjawab pertanyaan yang berbentuk esay. Pertanyaan berbentuk esay sifatnya terbuka berorientasi pada proses dan mengundang berbagai alternatif jawaban menurut pemahaman yang diperoleh siswa setelah membaca komik. Pemilihan tipe pertanyaan menentukan respon proses dan berpikir siswa untuk menentukan jawabannya. Dalam proses pembelajaran penggunaan teknik bertanya sebaiknya berdampak pada pengembangan keterampilan proses bukan sekedar terhadap ingatan siswa. Pertanyaan dikatakan baik jika mengandung jawaban yang terkait isu penting serta menuntut proses berpikir (Bima dalam Subekti, 2018:83).

\section{SIMPULAN DAN REKOMENDASI}

Berdasarkan hasil analisis dan temuan hasil penelitian dapat disimpulkan bahwa media komik yang dikembangkan materi interaksi manusia dengan lingkungannya dalam pembelajaran IPS layak (Valid, Praktis, Efektif) digunakan dan meningkatkan keterampilan berpikir kritis siswa kelas V sekolah dasar.

Media pembelajaran ini sangat cocok untuk pembelajaran kapanpun dan dimanapun seperti yang terjadi pada masa pandemi Covid-19 agar pembelajaran tetap bisa terlaksana dan siswa terlibat secara aktif. Selain itu, media komik dapat dijadikan sebagai alternatif pilihan bagi guru atau tenaga pendidik untuk menyampaikan materi selain materi interaksi manusia dengan lingkungannya atau bahkan pada mata pelajaran 
selain IPS. Bagi Peneliti lain dapat mengembangkan media pembelajaran serupa dengan penyempurnaan dalam berbagai hal untuk mendapatkan hasil yang lebih optimal serta menambahkan variabel lain

\section{DAFTAR PUSTAKA}

Aqib, Z. (2015). Model-Model Media dan Strategi Pembelajaran Kontekstual (Inovatif). Bandung: Yrama Widya.

Arikunto, S. (2013). Prosedur Penelitian Suatu Pendekatan Praktik. Jakarta: Rineka Cipta.

Ariyanto, A., \& Laksana, S. D. (2017). Pembelajaran IPS dengan Media Komik Strip di kelas 4. Muaddib: Studi Kependidikan dan Keislaman, 7 (2), 188198.

https://doi.org/10.24269/muaddib.v7i2.8 01.

Arsyad, A. (2014). Media Pembelajaran. Depok: PT Raja Grafindo Persada

Budi, J. (2015). Membumikan Karakter sebagai Landasan Pengembangan Kemandirian Bangsa. Prosiding Seminar Nasional. Mataram: FKIP Unram

Bujuri, D. A. (2018). Analisis Perkembangan Kognitif Anak Usia Dasar dan Implikasinya dalam Kegiatan Belajar Mengajar. Literasi: Jurnal Ilmu Pendidikan, 9 (1), 37-50.

Depdiknas. (2003). Undang-Undang Republik Indonesia Nomor 20 Tahun 2003 tentang Sistem Pendidikan Nasional. Jakata: Depdiknas

Depdiknas. (2006). Permendiknas Nomor 22 Tahun 2006 tentang Standar Isi untuk Satuan Pendidikan Dasar dan Menengah. Jakarta: Depdiknas

Depdiknas. (2008). Permendiknas Nomor 2 Tahun 2008 pasal 6 tentang Buku. Jakarta: Depdiknas

Haryanti, D. W. (2017). Model Problem Based Learning Membangun Kemampuan Berpikir Kritis Siswa Sekolah Dasar. Jurnal Cakrawala Pendas, 3 (2), 57-63. https://doi.org/10.31949/jcp.v3i2.596.

Hasbullah. (2015). Dasar-Dasar Ilmu Pendidikan.
Jakarta: PT Raja Grafindo Persada

Hidayah, N., \& Ulva, R. K. (2017). Pengembangan

Media Pembelajaran Berbasis Komik

Pada Mata Pelajaran Ilmu Pengetahuan

Sosial Kelas IV. Terampil: Jurnal

Pendidikan Dan Pembelajaran Dasar,

4(1), 34-46.

https://doi.org/10.24042/terampil.v4i1.1

$\underline{804}$.

Laksana, S. D. (2015). Komik Pendidikan sebagai Media Inofatif MI/SD. Ta'allum: Jurnal Pendidikan Islam, 3 (2), 151-162. https://doi.org/10.21274/taalum.2015.3. 2.151-162.

Lanti, E, (2017). Media Pengembangan Pendidikan karakter Bagi Siswa Sekolah Dasar. Gorontolo: Athra Samudra.

Lismaya, L. (2019). Berpikir Kritis \& PBL. Surabaya: Media Sahabat Cendekia

Mawardi, M. (2019). Rambu-rambu Penyusunan Skala Sikap Model Likert untuk Mengukur Sikap Siswa. Scholaria: Jurnal Pendidikan Dan Kebudayaan, 9 (3), 292-304.

Musfiqon. N. (2015). Pendekatan Pembelajaran Saintifik. Sidoarjo: Nizamia Learning Center

Nasution. (2015). Kajian Pembelajaran IPS di Sekolah. Surabaya: Unesa University Press.

Nida, I. K., Buchori, A., \& Murtianto, Y. H. (2017). Pengembangan Comic Math dengan Pendekatan Etnomatematika pada Materi Kubus dan Balok di SMP. Aksioma: Jurnal Matematika dan Pendidikan Matematika, 8 (1), 31-40. https://doi.org/10.26877/aks.v8i1.1531.

Nieveen, N. (1999). Prototyping to Reach Product Quality. Dalam Plomp, T; Nieveen, N; Gustafson, K; Branch, R.M; dan van den Akker, J (eds). Design Approaches and Tools in Education and Training. London: Kluwer Academic Publisher

Pidarta, M. (2013). Landasan Kependidikan. Jakarta: PT Rineka Cipta

Prayitno, L. (2015). Profil Kemampuan Berpikir Kritis Siswa SD di Kecamatan Blurak. Surabaya: Universitas PGRI Adi Buana. 
Pribadi, B. A. (2017). Media dan Teknologi dalam Pembelajaran. Jakarta: Kencana

Putri, R. A., Fida, R., \& Wasis. (2018). The Development of Biology Comic Education with $\mathrm{CaC}$ Method to Improve $10^{\text {th }}$ Grade Student's Literacy. IOP Conference Series: Journal of Physic 1108, 1-6. https://doi.org/10.1088/17426596/1108/1/012028.

Razak, F. (2017). Hubungan Kemampuan awal terhadap Kemampuan Berpikir Kritis Matematika pada Siswa Kelas III SMP Pesantren IMMIM Putri Minasatene. Mosharafa: Jurnal Pendidikan Matematika, 6 (1), 117-128. https://doi.org/10.31980/mosharafa.v6i1 .299 .

Ridha, A., Pradana, T. D., \& Mayarestya, N. P. (2017). Pengaruh Media Komik terhadap Pengetahuan Kesehatan Mata pada Anak. Jurnal Vokasi Kesehatan, 3 (2), 61-66. https://doi.org/10.30602/jvk.v3i2.111.

Riduwan. (2013). Skala Pengukuran Membaca di Sekolah Dasar. Jakarta: Bumi Aksara.

Riyanto, Sugianti. (2020). Teori Pengembangan Model Addie dan R2D2. Pasuruan: Lembaga Academic \& Research Institute.

Rohaendi, S., \& Laelasari, N. I. (2020). Penerapan Piaget dan Vygotsky Ruang Lingkup Bilangan dan aljabar pada Siswa Mts Plus Karangwangi. Jurnal Prisma, 9 (1), 65-76. https://doi.org/10.35194/jp.v9i1.886.

Rosidah, A. (2016). Penerapan Media Pembelajaran Visual Untuk Meningkatkan Pemahaman Konsep Siswa Pada Mata Pelajaran IPS. Jurnal Cakrawala Pendas, 2 (2), 121-126.

Rosyada, D. (2012). Media Pembelajaran: Sebuah Pendekatan Baru. Jakarta: Gaung Persada (GP) Press.

Rusman., Riyana, C., \& Kurniawan, D. (2013). Pembelajaran Berbasis Teknologi Informasi dan Komunikasi: Mengembangkan Profesionalitas Guru. Jakarta: PT Raja Grafindo Persada
Sadiman, A. S., Rahardjo, R., Haryono, A., \& Rahardjito. (2014). Media Pendidikan: Pengertian, Pendidika, dan Pemanfaatannya. Jakarta: Rajawali Pers

Saputra, A. D. (2016). Implementasi Media Pembelajaran Komik Islam untuk Meningkatkan Prsstasi Belajar dalam Berpikir Kritis Siswa di Sekolah. Ulul Albab: Jurnal Studi Islam, 17 (1), 110133. https://doi.org/10.18860/ua.v17i1.3264.

Setyowati, R., \& Firmansyah, W. (2018). Upaya Peningkatan Citra Pembelajaran IPS bermakna di Indonesia. Jurnal Pendidikan Ilmu Pengetahuan Sosial Indonesia, 3 (1), 14-17. https://doi.org/10.26737/jpipsi.v3i1.544.

Silva, A. B. D., Santos, G. T. D., \& Bispo, A. C. K. D. A (2016). The Comics as Teaching Strategy in Learning of Students in an Undergraduate Management Program. Mackenzie Management Review, 18 (1), 40-65.

Subekti, S. (2018). Mencetak Generasi Cerdas Melalui Berpikir Kritis. Surabaya: CV. Cipta Media Edukasi.

Sudjana, N., \& Rivai, A. (2011). Media Pengajaran. Bandung: CV Sinar Baru Algesindo.

Sugiyono. (2018). Metode Penelitian Kombinasi. Bandung: Alfabeta, CV.

Sugiyono. (2019). Metode Penelitian Kuantitatif, Kualitatif, dan $R \& D$. Bandung: Alfabeta.

Sukamadinata, N. S. (2013). Metode Penelitian Pendidikan. Bandung: PT. Remaja Rosdakarya.

Sukmanasa, E., Windiyani, T., \& Novita, L. (2017). Pengembangan Media Pembelajaran Komik Digital Pada Mata Pelajaran Ilmu Pengetahuan Sosial Bagi Siswa Kelas V Sekolah Dasar Di Kota Bogor. Jurnal Pendidikan Sekolah Dasar, 3 (2), 171-185. http://dx.doi.org/10.30870/jpsd.v3i2.213 8.

Sundayana, Rostina. (2016). Statistika Penelitian Pendidikan. Bandung: Alfabeta

Surahman, E., \& Mukminan. (2017). Peran Guru 
IPS Sebagai Pendidikan dan Pengajar Dalam Meningkatkan Sikap Sosial dan Tanggung Jawab Sosial Siswa SMP. Harmoni Sosial: Jurnal Pendidikan IPS, 4 (1), 1-13. https://doi.org/10.21831/hsjpi.v4i1.8660

Suryani, N., \& Putria, A. (2018). Media Pembelajaran Inovatif dan Pengembangannya. Bandung: PT Remaja Rosdakarya.

Susanto, A. (2014). Tujuan Pembelajaran IPS di Sekolah Dasar. Jakarta: Prenadamedia Group.

Thiagarajan, S. Semmel, D.S \& Semmel, M.I. (1974). Intructional Development for Training Teacher of Expectional Children. Minnesota: Leadership Training Institute/ Special Education, University of Minnesota.

Ulwiyah, N. (2014). Optimalisasi Metode Pembelajaran IPS MI untuk Pengembangan Keterampilan Berpikir Kritis Siswa. Religi: Jurnal Studi Islam, 5 (2), 169-200.

Widyanti, A., \& Prodjosantoso, A. K. (2015). Pengembangan Media Komik IPA untuk Meningkatkan Motivasi Belajar dan Karakter Peserta Didik SMP. Jurnal Inovasi Pendidikan IPA, 1 (1), 24-34. https://doi.org/10.21831/jipi.v1i1.4529.

Winataputra, S, U. (2010). Materi dan Pembelajaran IPS SD. Jakarta: Universitas Terbuka

Winataputra, S. U., Delfi, R., Pannen, P., \& Dina, M. (2014). Teori Belajar dan Pembelajaran. Jakarta: Universitas Terbuka.

Yonanda, D. A., Yuliati, Y., \& Saputra, D. S. (2019). Development of Problem Based Comic Book as Learning Media for Improving Primary School Students' Critical Thinking Ability. Mimbar Sekolah Dasar, 6 (3), 341-348. https://doi.org/10.53400/mimbarsd.v6i3.22892.

Zakiah, L., \& Lestari, I. (2019). Berpikir Kritis dalam Konteks Pembelajaran. Bogor:
Erzatama Karya Abadi.

Zubaidah, S. (2010). Berpikir Kritis: Kemampuan Berpikir Tingkat Tinggi yang dapat dikembangkan melalui Pembelajaran Sains. Makalah disampaikan pada Seminar Nasional Sains 2010. Surabaya: Pascasarjana Universitas Negeri Surabaya. 